\title{
Kaupapa Māori in New Zealand public libraries
}

\section{by Luqman Hayes}

Submitted to the School of Information Management, Victoria University of Wellington in partial fulfilment of the requirements for the degree of Master of Information Studies 


\section{Acknowledgements}

I would like to thank my supervisor, Dr Brenda Chawner, for her clear guidance, reassurance and encouragement throughout this project. I would also like to express my gratitude for the assistance and input of Dr Loriene Roy in providing an indigenous perspective on the study.

Big thanks to all my colleagues at Whakatāne Library who have backed and inspired me on this journey, keeping me laughing along the way.

To the people who took part in the study, I particularly acknowledge the time you took out of your busy schedules to assist me and thank you for your honesty and openness in the ways you contributed.

Lastly I must convey my immense appreciation and aroha for my family: Isla, Torin and Aaron and my partner Anna for their patience, wisdom and support.

Luqman Hayes

31 October 2012 


\section{Contents}

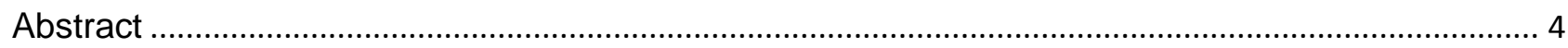

1.0 Introduction and topic statement

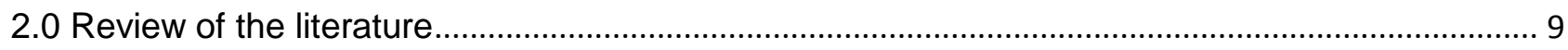

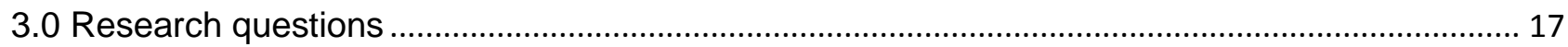

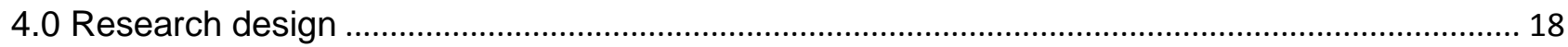

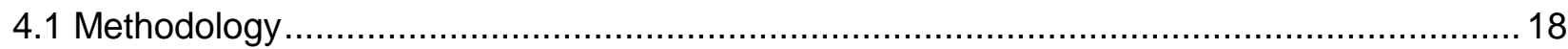

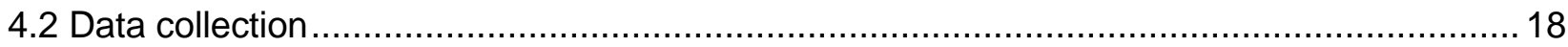

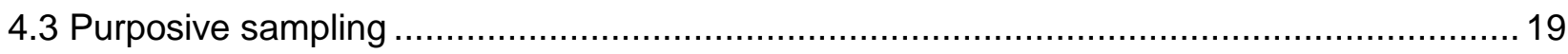

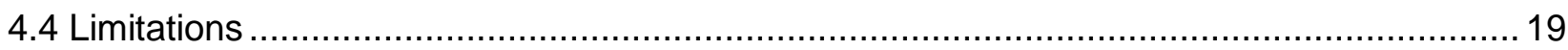

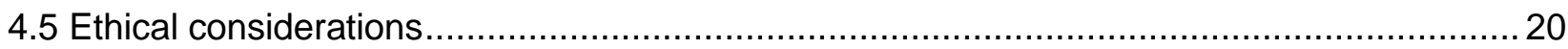

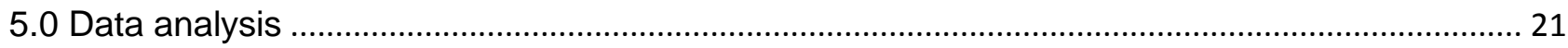

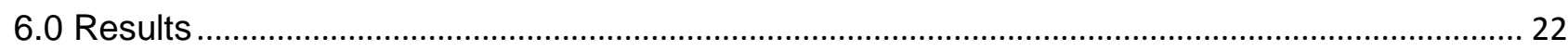

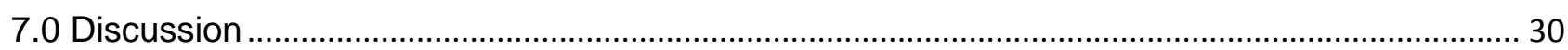

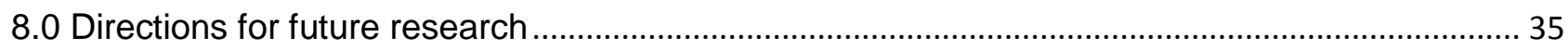

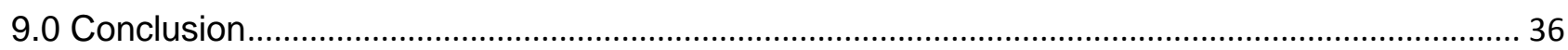

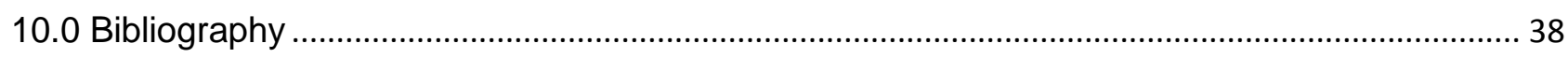

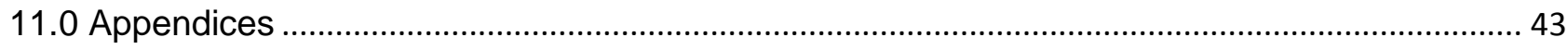

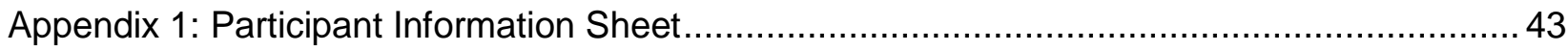

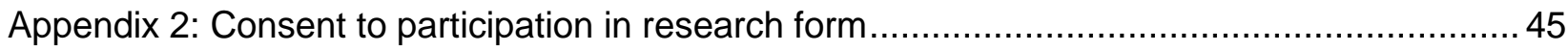

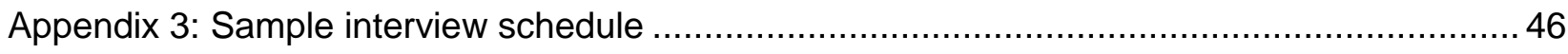




\section{Abstract}

It is nearly two decades since Tui MacDonald first studied the experience of Māori in New Zealand libraries. Since then libraries have seen many changes and embraced challenging initiatives in creating public spaces which reflect much of the biculturalism of New Zealand society. Bilingual signage has been erected, awareness and obligations to the Treaty are generally better accepted and understood, and Te Rōpū Whakahau has helped to ensure there is a growing professional Māori presence in our libraries. But is that enough? Should biculturalism not be aiming to integrate Māori values and concepts in the ideals of the organisation? Should biculturalism not reflect an equal representation of both the Pākehā (non-Māori) and the Māori worldview in the way information is organised, customers are greeted and activities are carried out in the library?

This research project explores the deeper commitments to biculturalism by examining the extent to which kaupapa Māori, or Māori knowledge frameworks, value systems, and a Māori worldview form part of a wider bicultural strategy within public libraries in Aotearoa. The study highlights the bicultural achievements being made in public libraries as well as exploring the evolutionary and transformative challenges which lie ahead for the sector in striving towards an epistemological and cultural balance.

Data for this research was collected using a qualitative approach involving semi-structured interviews with a selection of library leaders chosen from a purposive sample of public library services in New Zealand.

The findings suggest a degree of inconsistency around the integration and understanding of kaupapa Māori concepts and practice, depending on location and demographic. They indicate that while there are personal, organisational and resource barriers to fully incorporating a kaupapa Māori, including a lack of Māori seniority within the industry, these limitations stem from political and historical roots which relate to colonialism in Aotearoa and the commitment to, and interpretation of, the Treaty of Waitangi. The results also reveal an aspiration for advancing the bicultural agenda and for exploring new paradigms for reshaping European designed public libraries in ways which integrate indigenous worldviews. 
As a contribution to the library and information sector body of knowledge, the subject has significance not only within New Zealand but globally, particularly in relation to the incorporation of indigenous worldviews in library design, development and delivery. Opportunities for further research include exploring Māori representation in public library management, options for altering library classification systems and collection arrangements to integrate indigenous worldviews and staff experiences of kaupapa Māori.

Keywords: biculturalism, New Zealand public libraries, indigeneity, Māori, kaupapa 


\subsection{Introduction and topic statement}

This research study explores the bicultural initiatives and practice taking place within public libraries in Aotearoa New Zealand that engage kaupapa Māori. The project examines the extent to which Māori knowledge frameworks and value systems and the incorporation of a Māori worldview form part of a wider bicultural approach.

Kaupapa Māori has been defined as "general principles" or "first principles" and the basis from which tikanga (custom) are formed and carried out whilst also being interconnected (Marsden 2003, p.66). Kaupapa Māori gives meaning to the life of Māori (Walker 1996, as cited in IRI 2000, p.3), and as a philosophy has been adopted in the development of Māori education as conceptualising Māori knowledge (Nepe 1991, as cited in IRI 2000, p. 3).

Kaupapa Māori as theory is an evolving set of concepts which should be understood as "multiple" rather than "a singular, universal way of being" (IRI 2000, p.4), reflecting the diverse nature of Māori iwi and hapū. With its roots in te reo Māori, Māori culture and tino rangatiratanga (or self-determination), kaupapa Māori has expanded to operate as a critique and a challenge to Pākehā hegemony and the othering of Māori (IRI 2000, p.11). Lee (2005) has emphasised the "transformative" relevance of kaupapa Māori in relation to tino rangatiratanga and the Treaty of Waitangi by providing "a framework from which to reconceive of our social circumstances, our predicaments and the multiple experiences of 'being Māori'" (Lee 2005 pp. 3-4). In this context kaupapa Māori operates as a counterpoint to the scientific positivist discourses that position Māori as 'other'.

Hence, kaupapa Māori is identified here, and in the context of its application to New Zealand public libraries, as having significance beyond the physical changes which have thus far symbolised biculturalism, such as the adoption use of bi-lingual signage, the creation and maintenance of a Māori collection and recruitment of Māori library staff. Rather its meaning is understood to be one where a Māori worldview and Māori philosophies are incorporated as both a complement and a challenge to the ways in which public libraries are perceived and operated.

Biculturalism is often loosely understood as partnership and power sharing between Māori and Pākehā without recognition for its historical and political roots and obligations in the 
Treaty of Waitangi. As kaupapa Māori theory suggests, that recognition necessitates a more radical and transformative realignment within New Zealand society beyond the surface level of token appreciation for a non-European culture. As Dick Grace has defined it, within a library context, biculturalism is "an organisational strategy based on the spirit and intent of the Treaty...an acknowledgement of the primacy of the tangata whenua, the indigenous people of the land...and aims to include Māori values and perspectives in the polices, practices and procedures of the organisation" (Grace in Garraway \& Szekely 1994, p.6).

This research examines the ways in which the values to which Grace refers have been instilled in public libraries. Previous research on biculturalism and libraries is outlined in the literature review section and reveals both a lack of recent literature on the wider subject and a distinct gap in research on the topic as relating to kaupapa Māori. The study asks what libraries have done or could do to implement initiatives and change which accommodate a Māori worldview, such as by applying the Library and Information Association of New Zealand Aotearoa (LIANZA) Body of Knowledge 11 guidelines which address awareness of indigenous knowledge paradigms (LIANZA n.d.). The research also questions whether libraries and librarians understand what is meant by kaupapa Māori and whether or not the profession is capable of the kind of paradigm shift that biculturalism requires.

This research has particular national and international relevance particularly given the National Library's responsibility to support all public libraries in New Zealand, and for actions and outcomes of its bicultural strategies to "feed into library networks around the nation and the world" (National Library of New Zealand 2010, p.5). The benefits of this research will be to both librarians and users of libraries. Within New Zealand, the study will help those within the library and information sector to understand the importance of including a Māori worldview in bicultural strategies in order to better serve the needs of Māori communities, whilst also benefiting Māori by making libraries more culturally relevant, accessible and reflective. As Aroha Chamberlain states: "If you commit to the Treaty of Waitangi then there should be no problem [in embracing bicultural initiatives]...You don't have to be a librarian to meet Māori needs, you don't even have to be Māori. What you do need is a commitment to the Tangata Whenua and a desire to see the Treaty of Waitangi partnership happen" (Chamberlain 1998, p.14). 
This study also contributes to the discourse within the library and information profession that seeks to learn from and explore opportunities for utilising indigenous knowledge paradigms in a public library context. 


\subsection{Review of the literature}

This proposal has found no known studies to date which directly examine the application of kaupapa Māori values and concepts in Aotearoa public libraries, nor their specific relevance in the context of biculturalism and the library industry. Searches using databases such as Library and Information Library and Information Science Abstracts and Library, Information Science and Technology Abstracts yielded few results which relate directly to the topic. Additional searches were carried out using the Scopus citation finder and Google Scholar. Some of the citations for this paper were derived from the reference lists of literature relevant to the topic.

The Research Archive of Victoria University of Wellington was explored for evidence of past research on the topic. A small number of investigations have been carried out into elements of the wider topic of biculturalism and New Zealand public libraries (such as Wara 2001 and Evans 2011) but none which examine the issues in relation to kaupapa Māori, Māori or indigenous worldviews and knowledge paradigms.

The majority of the papers selected here, while including considerations of kaupapa Māori, deal with issues of biculturalism largely from the perspective of provision of library services to Māori and access to information, particularly in urban centres. The growth of kaupapa Māori as a theoretical perspective and a praxis has thus far been exemplified in its entrenchment in the discourse of the education, health and social welfare sectors (IRI 2000). Nevertheless, this "bona fide theory of transformation" (IRI 2000, p.6) has yet to emerge in the library and information industry. The International Research Institute for Māori and Indigenous Education (IRI) discusses kaupapa Māori as evolving from other, similar expressions of "Māori aspirations" in recent history, including the discourse of Māoritanga (in the 1960s and 1970s) and biculturalism and taha Māori (the Māori perspective) in the 1980s. (IRI 2000, p.4). It is notable that for the IRI, biculturalism is located at a specific moment in time and that it has perhaps either stalled as a discourse in the field of library and information studies or that the sector has failed to keep pace with the changing discourse around biculturalism and the emergence of kaupapa Māori as a theoretical force.

Nevertheless, this literature shows us that Māori value systems are integral to 
biculturalism, even if they have not been prioritised in the majority of bicultural developments in libraries thus far. In doing so, the literature also provides a theoretical perspective which demonstrates that biculturalism which promotes a Māori worldview is historically rooted in the Treaty of Waitangi (including the Māori version Te Tiriti o Waitangi and all that implies in terms of tino rangatiratanga and unresolved issues of sovereignty) and while seeking partnership and power sharing, operates as a challenge to dominant, colonially established, European epistemologies.

The majority of literature that relates to the concepts of kaupapa Māori stems from the Te Ara Tika project (MacDonald 1993, Szekely 1997). These two publications, along with Ka Mahi Tonu (Garraway and Szekely 1994) lay the foundations for assessing Māori information needs in developing a bicultural strategy for New Zealand libraries and for exploring the barriers to wider Māori use of and participation in library services. MacDonald's largely qualitative investigation focuses on biculturalism and services to Māori from the perspective of the profession, revealing, among other findings, a lack of written bicultural and Treaty policy in many libraries, and an imbalance in the number of skilled Māori librarians. Szekely (1997) gathers the views of Māori users and non-users using six countrywide hui (meetings) which highlight a wide range of areas in which libraries are not meeting the information needs of Māori in terms of the library environment, its institutional and professional culture and its collections and access to them. In particular, the study demonstrates that libraries are lacking in specialist knowledge of Māori information and taonga, including the protocols around its storage and access to it. It also shows the need for a service which is culturally more sensitive, bilingual and more relevant to Māori.

Ka Mahi Tonu ('we are still working on it') (Garraway \& Szekely 1994) contains data collected from New Zealand libraries on bicultural initiatives established at the time. The overall aim of the publication is to demonstrate momentum along the path to bicultural libraries. It is also an opportunity to recalibrate the strategy with which biculturalism might be achieved in libraries, something which is outlined in a chapter by Dick Grace. Grace's four-stage process of "bicultural reformism" (Grace in Garraway \& Szekely 1994, p. 6) has an influential place in the Te Ara Tika project and is relevant for its main emphasis which is the blending of Māori and non-Māori concepts in altering organisational behaviour and culture. 
The views expressed in Te Ara Tika have been challenged by Smith (2008) in a largely quantitative study which lacks methodological and theoretical substance. Smith uses the findings of a very small sample of Māori and non-Māori library users to disprove the assertion that Māori differed from non-Māori in their information needs and perception of libraries. Smith concludes, against the tide of research to the contrary, that biculturalism serves no "significantly useful purpose" in libraries (Smith 2008, p. 22).

Although more than a decade old, the Te Ara Tika project has an important legacy in the discourse on biculturalism in New Zealand libraries. Data in Te Ara Tika: Guiding Voices (Szekely 1997) highlighting the ineffectiveness of Library of Congress subject headings for describing Māori topics, lead to the Māori subject headings (MSH) initiative. The research report which the $\mathrm{MSH}$ project produced collects opinion from students and staff at wānanga and universities as well as public library users using a combination of survey and hui (Simpson 2005). The study mainly examines difficulties experienced in accessing information specific to iwi which feeds into the MSH project. However, it also uncovers a need for cataloguers in particular to have knowledge of, or be trained in, te reo Māori and tikanga. Simpson's research is underpinned by the theoretical considerations of te Tiriti o Waitangi and the impact of the dominant (colonial) knowledge paradigm which Māori knowledge is subject to. The aims of the MSH are to reclaim Māori knowledge from the Crown house, to organise Māori knowledge on whakapapa principles (within the Tikanga Māori house) in order that the partnership aims of the Treaty house be achieved.

More recently Evans (2011) picks up the issue of bilingual signage in Aotearoa public libraries in a mixed methods study based on theories of library anxiety, the importance of wayfinding and a sense of belonging for Māori users. Evans' largely quantitative nationwide survey reveals an inconsistent picture where approximately 50 percent of New Zealand public libraries contain bilingual signage. As an indication of commitment to biculturalism, Evans' research suggests there is considerable room for improvement on this single issue. As one respondent in her study notes, significantly, "Signs as the only evidence of biculturalism might in fact be worse than a library with limited or no bilingual signs but instead a genuine engagement with the Treaty and needs of Māori in the community" (Evans 2011, p.54).

While research such as Evans' focuses on a single tenet, since Te Ara Tika there has been 
no further nationwide research which revisits the overall theme of biculturalism and its progress in New Zealand. Instead, studies have emerged from major urban centres which examine the broader bicultural themes. Auckland City Libraries carried out a large-scale survey of Māori library users and non-users by phone and paper-based questionnaires (Worth 1995). The aim of what remains the largest survey of its kind on this topic was to improve, and make more bicultural, services to Māori within the context of the New Zealand Library and Information Association's (now LIANZA) commitment to biculturalism and partnership working. From that viewpoint, the survey concludes as "unacceptable" the level of "discomfort" felt by Māori (Worth 1995, p.21) and highlights many of the concerns raised by Te Ara Tika, including the need for a bicultural strategy to focus on cultural awareness and better Māori representation amongst staff.

These outcomes are better contextualised in a paper to the Treaty Conference 2000 (Mamore \& Brubeck 2000) in which many of the bicultural developments which Auckland City Libraries initiated are outlined, including "Treaty at Work" training. As the authors note, Auckland City Libraries is an organisation which "is not based on Māori values. These must be brought to the institution" in a way which promotes biculturalism and provides a "Māori world view" (Mamore \& Brubeck 2000, p.130).

A follow-up to Auckland's 1995 survey was published seven years later which follows the same method from a smaller sample of 324 Māori residents of Auckland. The findings show signs that some of the bicultural issues have begun to be addressed but that gaps remain that might encourage better take up of library services by Māori, such as use of te reo Māori in the library and resources and staff knowledge to facilitate whakapapa research (Auckland City Libraries 2002).

On a smaller scale, Peters (2006), Campbell, Hutton \& Rewet (2004) and McCauley (2010) all consider the Māori cultural perspective in analysing services to Māori in Manukau, Wellington and Tauranga respectively. Peters (2006), survey of Māori residents in Manukau, while not robust as a research study given that it does not provide key methodological details, such as sample size or method of data collection, contains findings which are relevant to the research topic. For instance, Peters notes that barriers to Māori take up of library services include a need to develop a more approachable library staff able to relate to Māori better, aided by embedding a Māori component, via its bicultural strategy, 
Te Ao Marama, within the culture of all staff at Manukau libraries. Campbell, Hutton \& Reweti's (2004) assessment of the services to Mãori in Wellington public libraries is a unique document in the sense that it considers the library operation from a kaupapa Māori perspective, applying Māori values to the various tenets of the operation. The outcome of the study is a two-year customer care (or manaakitanga) plan which recommends the promotion of biculturalism "in all areas" of the library's work alongside training in te reo Māori, the Treaty in the workplace and understanding Te Ao Māori (the Māori worldview). McCauley (2010) is concerned with the significance of intellectual property rights for Māori and stresses the importance of consultation with iwi. The paper also presents further suggestions for widening awareness and education of these issues within the library industry, concluding that there is a need for librarians to deepen their understanding of tangata whenua and their role in supporting the Treaty in forging a more harmonious future.

At a national level, Mohi and Roberts (2009) outline the National Library of New Zealand Te Puna Mātauranga o Aotearoa's response to Māori services, Te Kaupapa Mahi Tahi: a Plan for Partnership. The strategy, which emphasises collaboration and consultation with iwi in all of its developments, is set in the context of Treaty obligations, recognition of te reo as an official language of New Zealand and the National Library of New Zealand Te Puna Mātauranga o Aotearoa Act of 2003. The significance of the Act, Mohi and Roberts note, is that "it recognises mātauranga Māori as a knowledge system" (2009, p. 50). Te Kaupapa Mahi Tahi, initially drafted for a two-year period to 2012 and due to be redrafted to 2017 , strategically sets out a pathway to achieving a status of being a "truly bicultural organisation" where "collection and service development and delivery are approached from a shared Māori and Pākehā world view" (National Library of New Zealand 2010, p.5). The plan incorporates key Māori concepts and is informed by qualitative research carried out on behalf of the National Library by Colmar Brunton, which notes the Library's need to "to better understand Māori models of learning and do more to integrate these models of learning within its activities" (National Library of New Zealand 2010, p.7).

Christchurch City Libraries' bicultural action plan 2008-2010, Te Ara Hou - the New Pathway, is one such example of Maori values being embedded within both a strategic framework and a set of tangible library development projects (Christchurch City Libraries 2008). A review of the former bicultural strategy for Christchurch, Ngā Tapuwae Hou, 
which included consultation with an extensive list of Maori stakeholders, led to the creation of Te Ara Hou. The new strategy has the Treaty and obligations to the Tangata Whenua as its starting point and is underpinned by Maori values and tikanga. While aiming to identify "future learner needs" it seeks to affirm "the knowledge and values of indigenous peoples in an age of information" (Christchurch City Libraries 2008, p. 4)

Outside of public libraries Tuhou (2011) explores some of the barriers which Māori encounter in university libraries using a methodology which combines a qualitative and a kaupapa Māori framework. His findings mirror much of what emerged from Te Ara Tika, particularly Tuhou's observation that Māori students who had experience of a Māori Studies department feel most comfortable in those culturally specific spaces. Among Tuhou's suggestions for minimising the barriers is "staff training to ensure that Māori students are engaged with in a culturally appropriate manner" (Tuhou 2011, p.38).

It is noticeable that in the period following Te Ara Tika little has been published which examines the progress of biculturalism in New Zealand libraries after such energetic beginnings (a gap which Chris Szekely noted in 2002). Furthermore, there has been little recorded evidence of the kind of paradigm shift within the industry to which Cullen (1997) refers and about which this research topic is concerned. Cullen argues that the momentum brought about by the creation of the Bicultural Special Interest Group and Te Ara Tika necessitates a change (or the recognition of tikanga) in the way libraries handle, store and give access to Māori information as well as the more institutional recognition of the Treaty as the nation's founding document and Māori as its first inhabitants. However, what is most significant to this review is the theme which underpins Cullen's discussion that the Western assumptions that form the basis of library practice and design need to be reconsidered in order to be fully bicultural. It is this validation of the knowledge structures of indigenous peoples such as Māori which, Cullen predicts, will force the "next major shift" (Cullen 1997, p. 8) in the philosophies around the library and information sciences as new cultural paradigms are embraced.

LIANZA's BOK 11 (LIANZA n.d.) framework for awareness of Māori knowledge paradigms, which is underpinned by kaupapa Māori values, is evidence of the industry's professional body's willingness to take steps towards this shift to which Cullen refers. While BOK 11 represents formal recognition of Māori philosophies, methodologies and knowledge as 
being a key element in the fundamentals of professional development for New Zealand library and information workers, that acknowledgement is not universal but reserved for those who pursue professional registration via bodies such as LIANZA.

Along with Cullen (1997) there is a healthy body of commentary, some of which is theoretical, which acknowledges the links between biculturalism, te Tiriti and the need to embrace a Māori worldview. Stevens (2004) and Johnston (2007) are concerned with the role which libraries have in the revitalisation and preservation of Te Reo and greater bilingual staffing of libraries in ensuring Māori information is handled in ways which are culturally appropriate. Jacobs and Falconer (2004) examine issues around managing Māori information in archives through Māori concepts such as kaitiakitanga (guardianship) and tino rangatiratanga (ownership or sovereignty) and suggest like many others, that partnership working under biculturalism should see archive staff trained in treaty issues, te reo and ngā tikanga. Henry (2001) argues that a "kaupapa Māori paradigm" should be adopted by libraries, archives and museums to both protect indigenous knowledge and taonga as well as to foster greater "understanding of and respect for Māori culture and knowledge" (p.16).

Roy (2007) provides an indigenous perspective on native use of libraries in Australia, North America and New Zealand, arguing that libraries have a social role within the community in facilitating and contributing to "a sense of individual and group pride and identity" for indigenous peoples (Roy 2007 p.4). Roy's sentiments are echoed by SinclairSparvier (2002) whose experience of Saskatchewan libraries' approach to serving its aboriginal communities has been one which demonstrates the potential for libraries to "empower people", by helping to transform their conditions and by preserving and "strengthening their cultural resources" (Sinclair-Sparvier 2002, p.8). Nakata (2005) in discussing the Aboriginal and Torres Strait Islander Protocols for Libraries, Archives and Information services, suggests a more radical approach to embracing indigeneity. He calls for indigenous culture to be at the core of Australian heritage and the library and information sector where it goes beyond "liberal intervention in the interests of equality or inclusion" to a place of "recognition...and, to some extent, reconciliation of different traditions" (Nakata 2005, p. 208)

Reegan Breu's discussion of what Canadian tribal band libraries can teach 'mainstream' 
public libraries resonates with the political drivers behind kaupapa Māori. Breu argues that public libraries assume an inherently contradictory political neutrality, one which serves the "prevailing political and economic ethos" (Breu 2003, p. 254). Band libraries teach us to challenge and "deconstruct" the ideologies underpinning mainstream libraries which reinforce unequal power structures. Breu also notes that for more equal partnership with Aboriginal peoples to take place in mainstream libraries, relationships need to be built, along with "social, physical and cultural spaces" which enable Aboriginal people to "participate and make decisions about public libraries and librarianship." (Breu 2003 p.256).

Maina's (2012) study of traditional knowledge management and preservation as applied to the library and information sector in Canada reveals the need for training in cultural awareness among the profession in order to embrace indigenous worldviews and pedagogies in their practice. Maina calls for an "in-depth involvement with Indigenous Peoples and their cultural practices" particularly amongst the communities that libraries serve (Maina 2012, p. 24).

Evidence from Christchurch, Auckland, Manukau, Wellington and Tauranga presented here indicates that bringing Māori value systems into library practice has occurred or is beginning to take shape in particular libraries. These examples will help to inform the study by providing a context in which it might be possible to ask what other libraries, particularly those outside of the main urban centres, about which there is clearly a gap in the literature, could do to implement such initiatives. They also prompt the question of whether or not the industry is capable of the kind of epistemological realignment which is the aim of biculturalism. 


\subsection{Research questions}

To what extent do kaupapa Māori, or Māori knowledge frameworks, value systems and a Māori worldview form part of a bicultural strategy within the public libraries of New Zealand?

\section{Sub-questions:}

In what ways is kaupapa Māori being implemented in New Zealand libraries?

What are the variations between different libraries in strategies around the implementation of kaupapa Māori?

What challenges and opportunities does the inclusion of kaupapa Māori in bicultural strategies pose to Aotearoa public libraries?

If barriers exist, how might they be overcome? Where opportunities are emerging, how might they be realised? 


\subsection{Research design}

The research involved interviews with a non-representative cross-sectional sample of New Zealand public library managers and a selection of senior library personnel. The project adds to the examples outlined in the literature review by assessing some of the bicultural initiatives which have been developed in particular library services with regard to kaupapa Māori.

\subsection{Methodology}

The study was carried out using qualitative methods in the form of semi-structured interviews with library managers and senior library personnel chosen from a purposive sample of ten public libraries within Aotearoa New Zealand.

Library managers, co-ordinators of library services and library team leaders were assumed to be those with responsibility for working within institutional values and goals and therefore best placed to assess whether and to what extent kaupapa Māori has been or could be incorporated within these institutional principles. In addition, some senior library personnel were selected in order to obtain Māori perspectives in the research.

A qualitative approach enables information to be gathered on the level of understanding of kaupapa Māori within the context of biculturalism in libraries, the kinds of initiatives that have been developed which relate to kaupapa Māori, why they have been initiated, and when and how these initiatives have come about. It harvests opinion on the successes and challenges encountered in implementing such bicultural strategies and yields some of the deeper political, cultural and attitudinal data around the issue of biculturalism. Finally, the research reveals areas for further development and improvement in the progress of biculturalism within the public library industry, particularly around addressing challenges or concerns which the research raises.

\subsection{Data collection}

Invitations to take part in the research were sent to public library managers and senior library personnel. From the responses, a selection of libraries aimed at representing a cross-section of district, provincial and urban library services was chosen. 


\subsection{Purposive sampling}

Given that some data relating to the topic is already in evidence from some of the large urban centres in New Zealand, as outlined in the literature review, the intention was to focus the majority of the data collection away from the major cities. Data was collected from six small and medium library services (level two and three), with the remaining four interviews carried out with large services (level one), including three from the major New Zealand cities. Libraries were selected using data from the Association of Public Library Managers (APLM) Public Library Statistics (LIANZA 2011). In addition, in selecting libraries for this study, figures from Statistics New Zealand (Statistics New Zealand 2006) were also consulted in giving consideration to the proportion of Māori living within a selected district. The aim of this approach was to provide a balance and comparison between high and low levels of Māori population as well as between a variety of library sizes. The data acquired from this cross-section of library services provides a rich comparison of experiences based on the variety of demographic, cultural and economic variables.

Interviews were carried out either by phone (four) and Skype video conference (five) with one interview taking place face to face on site at a library. A copy of the interview schedule is included in appendix 10.3 of this report.

\subsection{Limitations}

While the research aimed to provide a picture of the level of engagement with kaupapa Māori in New Zealand libraries, it is acknowledged that only a small cross-section of libraries was included in the sample. Given this, and the size of the research project, the findings are unlikely to be generalisable.

Due to financial and time constraints only one interview was carried out face-to-face with four via Skype video conference and five by phone. While this meant the researcher was unable to respond to cues that face-to-face contact might engender, it is felt that the method used did not detract from the quality of the data collected. Most interviews were of similar length, lasting approximately one hour. The shortest interview was thirty-three minutes and the longest one hour and sixteen minutes.

Only one public library manager identified as Māori in the initial sample, making it weighted 
heavily towards non-Maori opinions. Two senior library personnel were subsequently identified and included to allow better representation of Māori perspectives in the research.

Of the five level three libraries invited to take part in the research, only two chose to do so. This lack of take up represents a limitation in terms of small library perspectives in the research.

\subsection{Ethical considerations}

The research acknowledges that many of the issues which arise in this study may be considered of a politically or culturally sensitive nature and the utmost confidentiality has been exercised at all times.

Furthermore, this research, whilst not being carried out using kaupapa methodology is mindful of the historical and cultural sensitivities in relation to research on indigenous peoples and Māori in particular. The researcher, who does not identify himself as Māori, acknowledges that research on Māori has, for some, associations with barbaric practices carried out during the age of colonialism and imperialism in the development of dominant Western knowledge systems (Smith 1999).

Research participants were asked to sign a consent form which outlined the research's ethical guidelines, copies of which, along with an information sheet for participants are included in the appendix of this report. 


\subsection{Data analysis}

Following transcription of the interviews, a thematic analysis of the data was carried out using a grounded theoretical approach, allowing trends and patterns to emerge from the data. Key themes, opinion and common ideas were identified within the data, shaping the theoretical basis of the research.

Transcriptions began early in the data collection phase enabling an iterative strategy of data collection and analysis "in parallel" (Bryman 2008, p.545). This two-way technique helped to develop key analytical concepts with which to refine the research. It also served to identify unexpected aspects in the data and possible gaps in the overall thrust of the research questions. Such revisions allowed the researcher to restructure interview questions for subsequent data collection in order to accommodate new themes if necessary or to develop alternative techniques for drawing out concepts which hitherto may have been implied but not stated.

Once all the data were collected the themes which had been identified were analysed for relationships from which theory was constructed with consideration for factors external to the interview subjects themselves. These included, demographics of the library's location, the library's size and patronage (such as its visitor numbers and its general customer profile in terms of age, gender and ethnicity, where available). 


\subsection{Results}

From the interviews carried out there is scant evidence that kaupapa Māori, mātauranga Māori and Te Ao Māori form part of a formalised bicultural strategy within small and medium (that is, level two and three) public libraries in New Zealand. Most level one libraries in the sample do, however, demonstrate ways in which Māori kaupapa such as Te Reo, tikanga and kawa (protocol) are integrated into library policies, programming and procedures. However, one level one library stated emphatically that there was virtually no formalised Māori content in their institution's practice.

The findings show an awareness amongst library managers of the need to reflect Māori culture, or more accurately, the Māori communities local to each library. The extent to which that culture is being reflected varies, as does the degree to which staff and institutions have the resource, skill or motivation to embrace an indigenous worldview in the processes of their operations.

The data reveal overall a general understanding of kaupapa Māori amongst library leaders. The depth of understanding varies depending upon location and between Māori and non-Māori managers. Where Māori form a large proportion of the local population the Māori kaupapa are better understood and more readily applied on an informal basis. As one level two respondent notes: "It is implicit in everything we do... on an unspoken level it's integrated into what we do. On a spoken level we have an organisational obligation to follow the principles of the Treaty of Waitangi" [Level two library interviewee]. However, where Māori form a small percentage of an area's demographic, a more general, perhaps academic grasp of kaupapa Māori prevails amongst managers.

For Māori participants, kaupapa Māori is intuitive to how they operate. However, in some cases non-Māori managers express a good comprehension of kaupapa Māori in terms of its application of values and tikanga.

All participants in the study were aware of LIANZA's BOK 11 guidelines around indigenous knowledge paradigms. However, there was a significant amount of variation around their interpretation and application. Responses ranged from not wanting to adopt too prescriptive an approach to understanding or implementing Māori concepts, to clearly 
seeing how the guidelines could be interpreted and recalling examples of how they were applied.

For all of the participants in the research, reflecting a Māori worldview in public libraries is seen as important. In some cases it is seen as especially so given the organisational obligations under the Treaty of Waitangi and the significance of Māori being the indigenous people of Aotearoa.

The ways in which kaupapa Māori is expressed and applied within the libraries varies. Level two and three libraries tend not to have any particular Māori values formalised within their library policies and practice. Nor are Māori values built into the values of the local authority which governs their practice. Māori values and kaupapa form a part of the organisational strategies of some of the level one libraries which took part in the research. However, while there is clear commitment at a senior level within some of the level one public libraries, there is some evidence of difference of opinion on how or whether those kaupapa are applied effectively 'on the ground' and how they are filtered out to a large urban library network.

Among the challenges which the research revealed, fear is frequently cited as being a barrier to non-Māori staff embracing Māori customs in library activities and in using Te Reo in their interactions with Māori customers. Fear is also suggested by one level three library interviewee as being a possible reason for the low response rate from level three libraries to participate in the research. Where there is some evidence of resistance to incorporating Māori elements in library practice, the findings suggest this may be due to fear of mispronouncing words, making mistakes and causing offence. The following quotations from interviewees demonstrate succinctly the ways in which lack of confidence around Te Reo, tikanga and kawa can lead to feelings of discomfort, failure or of not being genuine:

I wouldn't say one would notice active resistance, what one would notice are fear, uncertainty - the fear of giving offence, culturally...the fear that people might put a foot wrong and not know what to do and therefore someone's going to be offended...it's quite a barrier to people learning. [Level one library interviewee] 
Several [staff] had made attempts to use Māori greetings to connect with Māori people....and very often had been rebuffed or their pronunciation had been commented on...It had made them feel quite uncertain. [Level three library interviewee]

We've got this horrible cultural cringe in this country where you don't want to be seen to be trying too hard. [level two library interviewee]

Coupled with these findings is the recurring theme that staff participating in Māori custom or protocol in library activities is in most cases reserved for special, Māori-relevant events, rather than part of the norm. By contrast there is a consistent picture from all the participants that the majority of library staff are keen to learn, to develop skills in Te Reo and Māori cultural awareness and are willing and open to trying new practices.

Amongst some managers there is a concern that formalising Māori cultural practice could be tokenistic in approach and, as is typified in the following quote from a level two manager, that it is preferable to be genuine in all elements of customer service:

I don't want to just do lip service and false and shallow. I think it needs to be imbued deep in an organisation and just seep out through its pores rather than wear a badge that says: we believe in Māori stuff. I think there's difference. [Level two library interviewee]

Training is identified by almost all participants as being of great importance in relation to the topic of kaupapa Māori. Māori staff, in particular, note the significance of Te Reo in understanding the Māori world, breaking down barriers, and as the words of the following interviewee highlight, providing a superior customer outcome:

If you had non-Māori who could korero Māori then I think Māori would be really happy with that... Māori don't want to have to repeat themselves; they don't want to have to keep spelling the words. You know, they get hoha. [Level one library interviewee]

Basic Te Reo training is available in the majority of cases through Councils. However, 
there is an incoherent or in some cases piecemeal approach to training around Māori issues and language and few libraries outside of the large services offer training which covers the Māori worldview and Māori protocols in depth. Some libraries discuss the lack of resource and funding for training in-house, insufficient time for staff resources and a concern over the lack of context and deeper understanding which ensures training is more than token. A lack of resource is also raised as a particular issue amongst smaller libraries with regard to Māori programming, outreach and service development.

While biculturalism is seen as being of importance to libraries, along with a representation of the Māori worldview, all participants agree that their libraries are not working in a bicultural way. The following respondent observations from the study are typical of many of the results:

Theoretically we embrace biculturalism. Practically we lose our way, I think. Possibly it's a non-event for three quarters of the staff. [Level one library interviewee]

We carry on more or less a monocultural service. We pay lip service to biculturalism, things like having Maori signage, but I wouldn't say that there's kaitiakitanga at all. There's no deep immersion of Māori values within the way that we're delivering our services. [Level one library interviewee]

A common theme to emerge from the interview data is that there is 'a long way to go' with biculturalism in Aotearoa. For some respondents, the perception is that the progress of biculturalism in New Zealand libraries has fallen short of its aims, as the following interviewee notes:

We haven't seemed to have come a long way in the last twenty years, you know, things have seemed to have stopped. We've managed to get things like bilingual signage and bilingual websites and Māori staff. But we seemed to have come to a halt now. There's no urge or push forward for, you know, more exciting things. [Level one library interviewee] 
Multiculturalism and diversity are discussed by several managers as being important for libraries in accepting and catering to a growing range of ethnicities. However, some respondents suggest that the agenda of multiculturalism is being used to divert priorities away from biculturalism, and in particular commitments to the Treaty, as this interviewee remarks:

That's why I think that nobody wants to talk about the Treaty, because if they talk about multiculturalism then they don't have to talk about the Treaty... that's what the huge problem is...the Treaty and things Māori are always in the too hard basket for most people. They don't want to go there for some reason. [Level one library interviewee]

The Treaty and adherence to it is raised, particularly by Māori respondents, as an important factor in libraries better reflecting the Māori worldview or the views of local iwi and hapū. Some respondents perceive that non-Māori do not understand the Treaty, or that they regard it as too difficult to implement or do not care about it. However, it is suggested by one respondent, as outlined in the quote below, that given the political negativity associated with it, it is the word Treaty itself which may need reconsideration. Such a revision, the interviewee suggests, may lead to a more coherent and enthusiastic application of the document:

There's a lot of negativity about the Treaty...people....hear the word Treaty and automatically barriers go up. It's about breaking down those barriers. Organisations especially local government need to look at sharing learnings ...get rid of the word Treaty and let's look at partnerships...Those messages that need to be communicated within organisations need to be simplified. ...What can you as an individual do to demonstrate that partnership? And those are very simple things like pronunciation...not being fearful of saying [names correctly] who the iwi are...names of marae. There's a lot of resources out there...it [partnership] needs to be in every single document from the policy right down to performance plans...it can be linked to customer service. [Level two library interviewee] 
There is a strong sense from the data which appears to support Breu's (2003) assertion, that public libraries in New Zealand cannot fully integrate a Māori worldview due to their being constructed upon Western and European knowledge paradigms within non- Māori designed buildings, and operated through local government structures which have been built on British colonial ideologies. While many of the study respondents are positive about the place of indigeneity in New Zealand public libraries, the following quotes from interviewees summarise the paradox which the partnering of the two worldviews presents:

They can but they don't sit happily inside the same institution. One of the things that we had started to do but never finished was to look at whether we should be delivering Māori services from the marae rather than trying to shoehorn them into a Western institution...We only got as far as consulting with the Māori community. We couldn't get agreement about where, which marae, which institution, we couldn't get agreement. It all got too hard. [Level one library interviewee]

I sort of put to [management] that what they ought to think about is having an indigenous library and what might that look like. And you know, we could be leading the way if we did that. But realistically I don't think that will happen. Probably it comes down to money. I think the only people that really push that way of thinking are Māori. It won't come from non-Māori. [Level one library interviewee]

Nevertheless, there is a strong indication from managers that incorporation of the Māori worldview within libraries can have profound enhancements for staff and the communities in which they are operating. The following interviewee's comments illustrate this point:

I am Pākehā ...I am comfortable sitting alongside a cultural process...I don't feel threatened by it. I feel it enriches my life and it is part of my community I live in. And I don't feel judged by not being an expert myself...so I can only think that people would resist partially because they feel threatened, personally. [Level two library interviewee]

The Māori subject headings project is held up as one positive example of connecting the 
two worldviews, although classifying Māori subjects using the Dewey decimal system is noted for inappropriateness as an Anglo-American model being applied to an indigenous knowledge system.

The shortage of Māori staff in libraries is raised as an issue in at least half of the cases. Several interviewees felt this was a factor which held libraries back from embracing more of a Māori kaupapa in their practices and continuing to progress biculturalism. While some libraries cite the positive impact of having a Māori specialist or takawaenga in their staff, it is acknowledged that such liaison positions are demanding, require high levels of responsibility and specialist knowledge. There is agreement that such positions are not senior enough within a library's staff structure and as a consequence place individuals under excess pressure.

As the next interviewee quote demonstrates, the observation is also made that in ensuring that Māori tikanga is carried out there is a danger that non-specialist Māori members of staff may be vulnerable to exploitation by employers:

[If] you have, say, a staff member who can do a powhiri, a staff member who can speak Māori and they suddenly become the be all and end all of all Māori engagement on behalf of the library...it may have nothing to do with their job description. But they become it. And the risk for that person is...they never successfully achieve what they're employed to do in their job descriptions and it can turn ugly. [Level two library interviewee]

By contrast, in order to protect Māori from such treatment, others, such as the interviewee quoted below, see the responsibilities around embracing Māori culture as being organisation wide:

[There is] a perception sometimes that tikanga is in the Māori speaking staff, that they are the ones that will carry the tikanga and be responsible for it...we all have obligations around tikanga. There are obligations around learning, there are obligations around giving it a try, there are obligations around listening and seeking to understand and asking Māori colleagues but not in the end expecting that one hundred percent of the 
effort will be our Māori colleagues doing it. We all have obligations. [Level one library interviewee]

Finally, there is not only a call for more Māori to be employed at a senior level in order to influence library policy, but also, as the quote below highlights, for a culture of trust and respect to be prevail in order for the Māori worldview to be meaningfully shared amongst colleagues:

The Māori staff within libraries need to be encouraged to share but then there's an issue of trust that the management teams or the environments within which Māori staff work, you have to create an environment for Māori staff, where they feel...that whatever knowledge they have is going to be treated with respect - this is the difference between Western and Māori cultures. [Level two library interviewee] 


\subsection{Discussion}

Defining in any precise or scientific sense what evidence of kaupapa Māori at work looks like is both problematic and contradictory to the myriad meanings which weave through the Māori worldview. Nevertheless, this study has been able to explore the ways in which kaupapa Māori is understood and expressed in public libraries.

What this study has found is a national picture which lacks coherence above any real absence of kaupapa Māori. Although lack of resource, opportunity and expertise within libraries are sometimes cited as affecting the wider integration of kaupapa Māori, the evidence of willingness among staff to embrace Māori philosophies, language and customs expressed by the range of small, medium and large library leaders in the study, suggests that the main reasons for this inconsistency may lie in wider, political structures and ideological frameworks which govern public libraries.

Furthermore, the results point to a reluctance to commit to biculturalism in this more profound sense of incorporating Māori philosophies within organisational values. By extension, this hints at an inability or unwillingness to adhere to the commitments of the Treaty, and to give space for the expression of tino rangatiratanga, as the comments from interviewees that follow exemplify:

I think a lot of it is lip service and tick the box. And I think they still fully don't understand the Treaty, and by 'they' I mean people in management. Māori, we obviously understand it and know how to implement things. But they still struggle with that, they don't quite understand how to implement things in their day to day work. And so that doesn't trickle down. [Level one library interviewee]

I think they find it really hard to understand. Or maybe some of them just don't care. That's the other thing. Maybe they don't want to either. [Level one library interviewee]

Observations here point to a political indifference to the Treaty despite corporate statements to the contrary from organisations. However, the lack of Treaty engagement 
commented on in the data has its roots in the political history of Māori - Pākehā relations, and can be viewed as a legacy of the colonial power relation which has, and apparently continues, to subjugate Māori. It is perhaps no coincidence that tino rangatiratanga is concept which is central to the expression of kaupapa Māori (IRI 2000, Lee 2005) or indeed that kaupapa Māori is interpreted by some as "a theory and practice of active resistance to the continued colonization of Māori people and culture" (Mahuika 2008, p.12). Full acceptance of the Māori worldview, including its aspirations of selfdetermination, as fundamental to a genuine commitment to biculturalism and the Treaty, can therefore be interpreted as not only problematic for the colonial (or post-colonial) governing structure, but a threat to the dominant cultural hegemony. It is from that standpoint that the promotion of multiculturalism in library discourse is interpreted, particularly by Māori in the study, as a diversion from these threats, as the quote below from an interviewee explains:

I think it's a red herring, myself. It's about getting your knitting right. It's about looking after your own backyard first and that's where biculturalism should always come first. That's not disrespecting any other cultures but unless you know who you are and your backyard is in order there's no way you can support anybody else. [Level two library interviewee]

The mindsets, attitudes and fears which emerge in the data are reflective of those constructed on the colonial ideologies to which Smith (1999) refers. For some participants in the study, many of these attitudes have been affected by social conditions. As one interviewee notes, "there are whole generations of people whose school education around the Treaty was zilch, or was pretty lacking in real historical context" [Level one library interviewee].

However, the data also suggest increasing openness and a shift in attitudes, perhaps lead by a younger generation who have benefitted from the changes brought about by the Waitangi tribunal, Māori resistance movements and the renaissance in Te Reo. The following respondent's remarks hint at that change:

I think our education system is getting better at educating children about Māori culture and learning Māori tikanga and stuff like that. For the older 
generation I think it's just a matter of being prepared to open their minds and become more knowledgeable about stuff. [Level three library interviewee]

Nevertheless, the absence of a strategic approach to integrating kaupapa Māori nationally suggests the unevenness with which the Māori worldview is understood and embraced within public libraries will continue. LIANZA's BOK 11 guidelines have a significant role to play in altering this imbalance. This research demonstrates, however, that without tying the guidelines to training, mentoring and partnership working in order to understand the concepts in action, and help to integrate them within library policy and practice, such guidelines may fail to fulfil their aim. They may also appear inaccessible and abstract to those without an existing and active knowledge of Māori tikanga, knowledge frameworks and value systems. Furthermore, while the appearance of Māori specialist library positions, including in some smaller, less resourced services represents an acknowledgement of the need for Māori culture to influence library practices, the lack of seniority afforded such roles points to an ongoing power imbalance between the two parties within the bicultural debate.

Based on this study, shifts in that relationship appear to be gradual and selective rather than radical and overarching, and therefore viewed by Māori respondents in particular, as welcome but inadequate. The data suggest that gaps in Māori representation at strategic positions within both libraries and their governing organisations are contributing to that power disparity and failing to influence policy in more fundamental ways which might integrate Māori values. As the following interviewee's remarks make clear, against this historical and political backdrop, radically transformative change is virtually impossible:

I would say from an organisational perspective, sometimes policies and procedures from within your organisation do not support the use of te reo Māori or even kaupapa Māori...probably because it's very old school. The history within organisations can be very long, and very traditional and very Western-based. So you may be coming up against a history of an organisation...so they're not going to be open to those kind[s] of changes. And sometimes it's a matter of small steps at a time. [Level two library interviewee] 
In such a political environment, and given their current design and structure, it is doubtful whether public libraries can accommodate the indigenous worldview on an equal basis with that of a Westernised, European influenced one. This is an observation which Māori contributors to the research, such as the following one, all offered:

Can I see a combination of the two? In all honesty, no, I don't think I can. You may find small pockets of it represented in some libraries. Do we have it in our particular library? I'd say no. We may have Māori information within a Western library but is that a representation of a Māori library? No. It is only a collection of information. [Level two library interviewee]

As this study confirms, Western and European methodologies prevail in the mainstream public library organisation of information and assume precedence over consideration for an understanding based on the philosophies or belief systems of iwi. It is for these reasons perhaps that all of the participants in this study felt their libraries to not be operating in a bicultural way. The quote below is one such a respondent example:

I don't consider us a bicultural library service. I think libraries are essentially pākehā institutions... and we are expecting to work biculturally when we are forming our actions. [Level one library interviewee]

What is clear, however, is that small changes are emerging to challenge the traditional arrangement of information, with the Māori Subject Headings project as a significant bridge between the two worldviews. The realisation from many in the research that the Dewey decimal system, for instance, is a 'limit' to integrating a Māori method of classification can also be interpreted as exposing the opportunity to radically transform the paradigms upon which public libraries are devised and run within Aotearoa.

The message that there is much further to go, to learn and to challenge libraries that frequently prevails in the data is both a concession that biculturalism has not achieved as much as would have been hoped, as well as an assumption that the process is a linear one which may even have a finite point of fulfilment. What this research shows is that biculturalism cannot meaningfully evolve outward without significant political and 
philosophical change at both the structural and agency levels. The interviewees' words below reveal what the implications for that change are for individuals and for the institutions in which they work:

What that does involve is you stepping outside of your comfort zone. Public libraries ...certainly are starting to do that and also need to do that a lot more...We're on the track but there is a long way to go. The question more is how far do you want go? I personally think we need to go a whole lot more, where that leads us to I'm not quite sure. [Level two library interviewee]

It does require us to have very different protocols and very different practices that our systems are not set up for. So it would require quite a lot of acceptance of new ways of thinking. It would require different operational structures...it's a full immersion thing; you can't just tack it on the side. [Level one library interviewee] 


\subsection{Directions for future research}

The range of issues and questions which have been raised by this study signify the directions for possible future research. They include, for example, exploring the possible options for modifying or redesigning library classification systems and collection arrangements to integrate indigenous worldviews.

Further studies might also seek to examine the reasons for the lack of Māori representation in public library management. And in continuity with, as well as a counterpoint to the present study, an exploration of staff experiences of encountering and participating in kaupapa Māori would also be relevant. 


\subsection{Conclusion}

This study highlights an aspiration for change among library managers to embrace, more meaningfully, the values and belief systems of Māori. It also reveals a number of the issues preventing that change from occurring successfully and with greater pace.

The wider, systemic issues which come to the surface in exploring Māori subjects in relation to non-Māori may be ones which the library and information sector cannot specifically address but which remind us that the bicultural relationship is not an equal one in terms of resource, representation and expression.

However, within the public library sector there is a clear need for strong direction and advocacy in order to drive a coherent, nationwide strategy for biculturalism which incorporates kaupapa Māori and which addresses the iniquities of resource between the different levels of public libraries in New Zealand. Coupled with that is a requirement for practical guidance, mentoring and partnership working, particularly where there is little engagement with iwi locally within libraries. The quote below from an interviewee, summarises the need for bold leadership in driving a more far-reaching bicultural strategy:

It's not just about putting up artworks and bicultural signage...you have to come through a cultural change about the way you look at things. That requires deep commitment at the highest level where it is set out in every policy in every line in every document, in my opinion...To a certain extent you can drive change from down under but unless it's right at the top level and incorporated in everything that comes through at a high level, then it comes back to my level and that is not good enough. [Level one library interviewee]

If biculturalism is to be taken seriously as a central pillar of the strategic future of public libraries, then change needs to be occurring both at the top as well as on the ground. This requires building partnerships with iwi and hapū, integrating Māori values and concepts and filtering them down through all the strata of the organisation; granting staff the training and support to actively engage in kaupapa Māori in relation to their communities. 
Rowena Cullen noted in 1997 that the library sector needed to work towards an epistemological transformation (p.8). The bicultural project in new Zealand has taken libraries a short way on that path but there is strong proof from this study that philosophical and political questions need to be asked of the profession if that transformation is to progress to a deeper and more meaningful stage.

The library environment, its policies and practice remain embedded with American and European concepts and paradigms. Where their patronage is higher amongst the pākehā population, the tendency may be not to consider how Mãoridom could influence the way the library is devised or run. Kaupapa Māori presents a challenge to this status quo, one which perhaps should not be considered a threat but a possibility.

If we are limited by Dewey or any other Western library classification system then is there a case for devising integrated classification systems for both indigenous and nonindigenous worldviews? Are there new ways to consider our approach to knowledge; its creation, its sharing and its care?

In an era when public libraries are perennially under threat of budget cuts and closure, could the intertwining of indigenous and non-indigenous worldviews, the creation of a unique and inclusive template for our libraries, be the way to forge a dynamic new future? Is there a way to transform our public libraries from the traditional paradigm to one which truly reflects indigeneity and multiculturalism without assuming the dominance of one cultural hegemony over all others? 


\subsection{Bibliography}

Auckland City Libraries (2002). The customer's voice II - another quest: improvement of services to Māori at Auckland City Libraries. Auckland, N.Z.: Auckland City Libraries.

Breu, R. D. (2003). Band and Tribal Libraries: What Mainstream Public Libraries Can Learn from Them? Feliciter 49(5): 254-257.

Bryman, A. (2008). Social research methods (3rd ed.). Oxford, New York: OUP

Campbell, J., Hutton, G., \& Reweti, A. (2004). Te Kohikohinga Māori: Manaakitanga : a two year Customer Care Plan. Wellington: Wellington City Libraries.

Chamberlain, A. (1998, July). Biculturalism in libraries. Library life te rau ora: Bicultural feature, 225, p.14

Christchurch City Libraries (2009). Te Ara Hou - Libraries Bicultural plan 2008 - 2010. Retrieved from http://christchurchcitylibraries.com/TeAraHou/TeAraHou.pdf October 2012

Cullen, R. (1997). Biculturalism and Librarianship in New Zealand: a More Fundamental Change than Information Technology. Paper presented at the 62nd IFLA General Conference. Retrieved from http://archive.ifla.org/IV/ifla62/62-culr.htm August 2010.

Evans, E (2011). An investigation into the extent and application of bilingual signage in New Zealand public libraries. Unpublished MLIS research project. Victoria University of Wellington. Retrieved from ResearchArchive @ Victoria 10 September 2011.

Garraway, J \& Szekely, C. (1994). Ka mahi tonu. Biculturalism in New Zealand librarianship 1992- $\quad$ 1994. Wellington: The N Strategy Bicultural Actions Group.

Grace, D. (1994). Bicultural Development. In J. Garraway \& C. Szekely (Eds.), Ka mahi tonu : biculturalism in New Zealand Librarianship, 1992-1994. Wellington, N.Z.: The N Strategy Bicultural Actions Group, in association with the New Zealand Library and 
Information Association Te Rau Herenga o Aotearoa.

Henry, E. (2001). The challenge of preserving indigenous knowledge: a model for collaboration between libraries and Māori. Library Life. 26, pp 13-16.

International Research Institute for Māori and Indigenous Education (IRI) with Te Rōpū Rangahau Hauora a Eru Pomare (2000). Māori Research Development: Kaupapa Māori principles and practices: a literature review. Research Report to Te Puni Kokiri, Wellington. June 2000. Retrieved from http://www.kaupapamaori.com/assets//Maori research.pdf March 2012.

Jacobs, T, \& Falconer, S. (2004). Ka mua, ka muri; Walking backwards into the future: Paths towards managing Māori information in archives. Archifacts, October, pp.1-20.

Johnston, L. (2007). The role of libraries and archival collections in the preservation and revitalisation of indigenous knowledge: The case of revitalisation of te reo Māori. New Zealand Library and Information Management Journal, 50(3), pp.202-215.

Library and Information Association of New Zealand Aotearoa (LIANZA) (n.d.). BOK 11. Awareness Of Indigenous Knowledge Paradigms, Which In NZ Context Refers To Māori. Retrieved 10 May 2012 from http://www.lianza.org.nz/career/professionaldevelopment/bok-11

LIANZA (2011). Public library statistics 2010/2011. Retrieved 27 April 2012 from http://lianza.org.nz/resources/lianza-documents/public-library-statistics/public-librarystatistics-20102011

McCauley, D. (2010). Tauranga City Libraries: Meeting the needs of local iwi? Biculturalism and Māori Cultural Property. The New Zealand Library \& Information Management Journal : Nga Purongo, 51(4), 247-267.

MacDonald, T. (1993). Te Ara Tika : Māori and libraries : a research report. Wellington N.Z.: New Zealand Library \& Information Association. 
Mahuika, R (2008) Kaupapa Māori theory is critical and anti-colonial MAI Review 3, Article 4. Retrieved August 2012 from http://www.review.mai.ac.nz/index.php/MR/article/viewFile/153/180

Maina, C. K. (2012). "Traditional knowledge management and preservation: Intersections with Library and Information Science." The International Information \& Library Review 44(1): 13-27.

Makoare \& Birkbeck (2000). He Awe Māpara: Reshaping the Māori face of Auckland Libraries in Proceedings of Treaty Conference 2000. Treaty Conference 2000 Publication Group. Auckland (pp.122-131).

Marsden, M (2003). Kaitiakitanga: A definitive introduction to the holistic worldview of the Māori. In Te Ahukaramū Charles Royal (Ed.), The Woven Universe: Selected Writings of Rev. Māori Marsden (pp. 54-72). Otaki: Te Wananga o Raukawa.

Mohi, J. H. \& Roberts, W.D. (2009). Delivering a strategy for working with Māori, and developing responsiveness to an increasingly multicultural population: a perspective from the National Library of New Zealand. IFLA Journal 35, (1), 48-58.

Nakata, M., Byrne, A.; Nakata, V.; Gardiner, O. (2005). Libraries, Indigenous Australians and a Developing Protocols Strategy for the Library and Information Sector. In; Nakata, M. \& Langton, M. (Eds.). Australian indigenous knowledge and libraries; (pp.196-210) Sydney, NSW. UTSe Press. Retrieved March 2012 from http://epress.lib.uts.edu.au/dspace/bitstream/handle/2100/57/Libraries\%20and\%20In digenous\%20Knowledge.pdf?sequence=1 .

National Library of New Zealand (2006). Te Kaupapa Mahi Tahi - A Plan for Partnership. Retrieved September 2011 from National Library of New Zealand. http://www.natlib.govt.nz/catalogues/library-documents/te-kaupapa-mahitahi/?searchterm=te\%20kaupapa\%20mahi\%20tahii

National Library of New Zealand (2010). Bicultural Implementation Roadmap 2010-2012. Retrieved November 2011 from National Library of New Zealand: 
http://www.natlib.govt.nz/catalogues/library-documents/bicultural-implementationroadmap-june-2010

Peters, S. (2006). Te Ara Tika ki Manukau: Staying the distance -- 2006 and beyond. Paper presented at Next Generation Libraries: Library and Information Association of New Zealand Aotearoa 2006 Conference, 08-11 October 2006, Wellington, New Zealand.

Roy, L. (2007). Indigenous Libraries and Innovative Multicultural Services. Paper presented at the (IFLA) International conference on Innovative multicultural library services for all. Pretoria, South Africa.

Simpson, S. (2005). Te Ara Tika: Guiding Words Ngā Ingoa Kaupapa Māori, Pūronga Tuatoru: Māori Subject Headings Project, Phase 3 Research Report. Retrieved September 2011 from http://www.trw.org.nz/publications/Te Ara Tika Guiding Words.pdf

Smith, L. T. (1999). Decolonizing Methodologies: Research and Indigenous Peoples. Dunedin: University of Otago Press.

Smith, T. (2008). Biculturalism in New Zealand libraries. New Zealand Library \& Information Management Journal, 51(1), 22-34.

Statistics New Zealand (2006). Quick stats about a place. Retrieved May 2012 from http://www.stats.govt.nz/Census/2006CensusHomePage/QuickStats/AboutAPlace.as $\underline{\mathrm{px}}$

Stevens, A. (2004). Are you Te Kaitiaki Pukapuka?:Bilingual staffing and ownership of Māori information. New Zealand Libraries, 49(11), 371-376.

Szekely, C. (Spring 2002). Te Ara Tika: Māori and libraries in New Zealand - staying the distance. World Libraries 12, 1.

Szekely, C. (1997). Te Ara Tika: guiding voices: Māori information needs. Wellington: NZLIA \& Te Rōpū Whakahau. 
Tuhou, T.M.P (2011) Barriers to Māori usage of university libraries: an exploratory study in Aotearoa New Zealand. Unpublished MIS research project. Victoria University of Wellington. Retrieved from ResearchArchive @ Victoria, September 2011.

Worth, H. (1995). The customer's voice - a quest: a survey: improvement of services to Māori at Auckland City Libraries. Auckland, N.Z.: Auckland City Libraries.

Wara, R. T. (2001). Case studies of successful implementations of bicultural policies and practices in Aotearoa New Zealand public libraries. Unpublished masters research project. School of Information Management. Victoria University of Wellington. New Zealand

Warren, G. T. (2006). Librarian myths and legends for Māori: He kupu, He whakaaro, He waiata. Unpublished masters research project. School of Information Management. Victoria University of Wellington. New Zealand. 


\subsection{Appendices}

\section{Appendix 1: Participant Information Sheet}

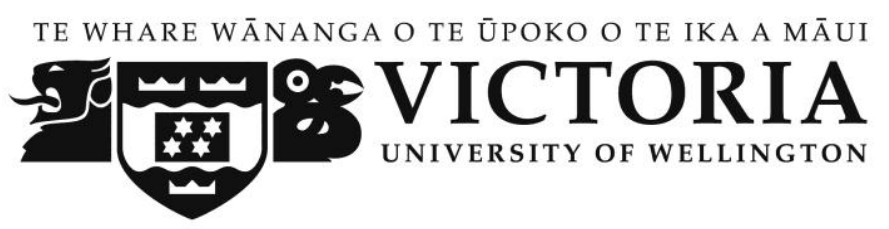

Participant Information Sheet for a Study of Kaupapa Māori in New Zealand public libraries

Researcher: Luqman Hayes: School of Information Management, Victoria University of Wellington

I am a Masters student in Information Studies at Victoria University of Wellington. As part of this degree I am undertaking an INFO 580 research project. The project I am undertaking is exploring the application of kaupapa Māori principles in bicultural approaches within public libraries in New Zealand.

The research aims to widen understanding and awareness of kaupapa Māori among participants and the library and information sector in New Zealand. It will also contribute to discourses around kaupapa Māori, biculturalism and indigeneity in relation to public libraries.

This project has received ethical approval from the School of Information Management Human Ethics Committee.

I am inviting public library managers to participate in this study. Participants will be asked to take part in semi-structured interviews lasting up to one hour, face-to-face or by internet video conference (Skype), phone or email. Interviews will be recorded and interview notes made.

If you would like to withdraw from the project, you may do so without question at any time before 5 August 2012.

The interview results will form the basis of my research project and will be included in a 
written report on a confidential basis. It will not be possible for you or your employer to be identified. Only grouped responses will be presented in this report. All material collected will be stored securely. No other person besides me and my supervisor, Dr Brenda Chawner, will see the interview transcripts or notes.

The final report of the project will be submitted for marking to the School of Information Management and deposited in the University Library. One or more articles based on the results may be submitted for publication in scholarly journals or presented at academic or professional conferences. Transcripts and notes from interviews will be destroyed two years after the end of the project.

A summary of findings from the project will be sent to participants at the conclusion of the project.

If you have any questions or would like to receive further information about the project, please contact me at hayesluqm@myvuw.ac.nz or my supervisor, Dr Brenda Chawner, at the School of Information Management at Victoria University, P O Box 600, Wellington, phone (04) 463 5780; email: brenda.chawner@vuw.ac.nz

\section{Luqman Hayes}




\section{Appendix 2: Consent to participation in research form}

TE WHARE WĀNANGA O TE ŪPOKO O TE IKA A MĀUI

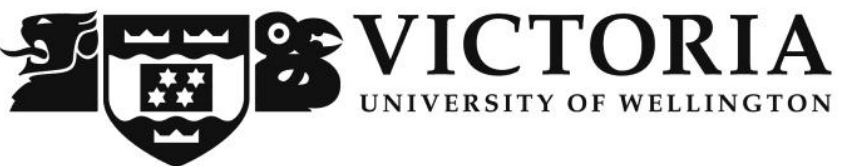

\section{CONSENT TO PARTICIPATION IN RESEARCH}

Title of project: Kaupapa Māori in New Zealand libraries

\begin{tabular}{|l|l|l|}
\cline { 2 - 3 } \multicolumn{1}{l|}{} & \multicolumn{1}{|c|}{$\begin{array}{c}\text { Yes } \\
\text { (Please tick) }\end{array}$} \\
\hline $\begin{array}{l}\text { I have been given and have understood an explanation of this } \\
\text { rave them answered to my satisfaction. }\end{array}$ & & \\
\hline $\begin{array}{l}\text { I understand that I may withdraw myself (or any information I } \\
\text { have provided) from this project (by 5 August 2012). I } \\
\text { understand that if I withdraw from the project, any data I have } \\
\text { provided will be destroyed. }\end{array}$ & & \\
\hline $\begin{array}{l}\text { I understand that any information I provide will be kept } \\
\text { confidential to the researcher and the supervisor. The published } \\
\text { results will not use my name and no opinions will be attributed } \\
\text { to me in any way that will identify me. }\end{array}$ & & \\
\hline $\begin{array}{l}\text { I understand that interviews will be recorded and that those } \\
\text { recordings will be electronically deleted at the end of the project } \\
\text { unless I indicate that I would like them returned to me. }\end{array}$ & & \\
\hline $\begin{array}{l}\text { I understand that the data I provide will not be used for any } \\
\text { other purpose other than this research project and that any } \\
\text { further use will require my written consent. }\end{array}$ & & \\
\hline $\begin{array}{l}\text { I would like to receive a summary of the results of this research } \\
\text { when it is completed. }\end{array}$ & & \\
\hline I agree to take part in this research & & \\
\hline
\end{tabular}

Signed:

Name of participant

(Please print clearly)

Date: 


\section{Appendix 3: Sample interview schedule}

1. What do you understand by the term kaupapa Māori?

2. What experiences have you had of kaupapa Māori within a cultural institution?

3. In what ways do you incorporate Māori values in the delivery of your library services?

4. What challenges or opportunities does the adoption of Māori values or customs present to your library, both amongst the staff and the wider public?

5. To what extent do you think it is important to reflect the philosophies and worldviews of Māori (or of particular iwi local to your library) in your library's service and delivery?

6. In what ways are Māori values included in the wider values of your institution, whether via a local authority or other organisational body?

7. In what ways do you involve Māori members of your community in library activities?

8. What ritual or formal welcomes do you have for groups (including Māori groups) visiting the library? Do they include Māori elements, such as a mihi or waiata?

9. In what other ways do you incorporate Māori custom?

10. Do staff in your institution undergo any kind of training (whether formal or informal) in:

- Te reo Māori

- Treaty of Waitangi issues

- Māori cultural awareness (tikanga etc.)

- Mātauranga Māori

11. What relationship, if any, does your library have with local iwi?

12. How familiar are you with LIANZA's BOK 11 guidelines for awareness of indigenous knowledge paradigms?

13. NZ public libraries are based on Western ideas/paradigms. To what extent can they realistically embrace an indigenous worldview such as Maori?

14. How important do you think it is for NZ libraries to operate biculturally?

15. What does a bicultural library look like? 
Kaupapa Māori in New Zealand public libraries

Word count: 10,433 